\title{
Fractality of concentric structures in space of ecologic-urban planning systems
}

\author{
Iryna Ustinova \\ Kyiv National University of Construction and Architecture \\ 31, Povitroflotskyy prosp., Kyiv, Ukraine, 03037 \\ irinnarx@gmail.com, orcid.org/0000-0002-1728-0200
}

The manuscript was received on 03.07.2017 and was accepted after revision for publication on 04.10.2017

DOI: $10.26884 / 1707.1902$

\begin{abstract}
Conditions and stages of formation of the fractally embedded set of concentric zones of accessibility of cities on the example of Kiev are considered. The number of "levels of embedding" of such a set depends on the attractiveness and status of the city.

It was established that discontinuity of space developing is associated with economic development and engineering and transport networks. A rapid growth of these networks leads to the transformation of the traditionally central type of irregularity of developing the space into the multinuclear clustered systems of settlement.

In the zone of Kiev influence, there are five qualitatively differed by intensity of socioeconomic links and speed of movement belts are distinguished. On the base of quantitative characteristics of these belts, it was established that in successive transition of developmental processes from local to regional and interregional levels of integrity of the ecologic-urban planning system "population $\leftrightarrow$ environment", the expansion of its spatial boundaries and peculiar "compression" of temporary ones occur that is manifested by intermittent increase in the radius of city's influence area - the center of system of settlement expressed in kilometers.
\end{abstract}

For analysis of processes of multi-level development of ecologic-urban planning systems, the dynamics of indices of development is not as much important as characteristics of their accelerations.

Keywords: sustainable development, fractality, spatial structures, ecologic-urban planning systems, areas of cities influence.

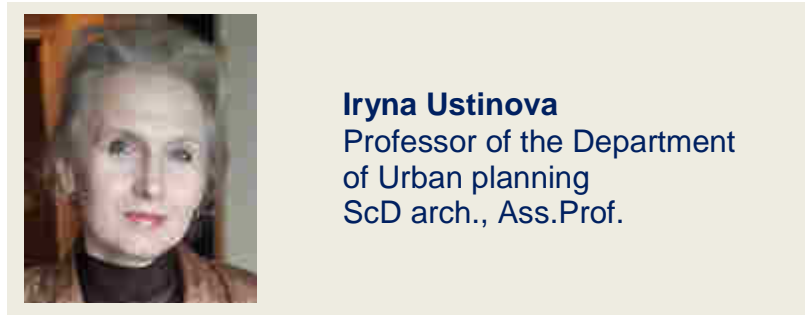

\section{INTRODUCTION}

Under contemporary conditions, the effectiveness of city's functioning becomes, more and more, dependent on the speed of city's transport. However, in the up-to-date world of means of mass communications that allow people to contact without moving in space, the problem arise whether it will lead to the radical restructures in the spatial organization of life activities of population?

Usually the intensity of traffic in the cities changes dependent on the distance to the city's center that is the objective reflection of general heterogeneity of city's space. In this nonuniformity prevails a directed to the center tendency of city's activity and appropriate to it type of spatial organization. Along with this, the increase of significance of transport communication network and in particular systems of high-speed communications, leads to a certain transformation of traditional central type of spatial non-uniformity. This process shows itself in the formation of multi-clustered plan- 
ning structures and group systems of settlement [1, p.62-66].

\section{MATERIALS AND METHODS}

The objective of investigation is in determination of fundamental principles of constant development of ecologic-urban planning systems (EUPS).

In the course of carrying out this work, a system approach, methods of modelling and comparative analysis were used. The analog method was chosen as the basic one that is the instrument of comparative analysis and is widely applied in ecology.

\section{STARTING POSITION}

In comprehension of modern science, development of any system - it is, first of all, the changes in its states that are determined by a set of values of basic characteristics of the system. For a town planning system - it is dimensions of the area of its territory, the number of population, functional-and-planning structure, engineering-and-transport network and form of settlement.

Development is a motion without which the nature cannot exist even for an instant. On the scale of planet, the acceleration of tempos of this movement is observed to which a development of any system is obeyed, including a town planning one [2 -5].

\section{FORMS OF SETTLEMENT}

Problems mentioned had been studied with many Ukrainian scientists-urbanists, in particular Yu.Belokon, M.Dyomin, G.Zablotsky, G.Filvarov, I.Fomin.

According to I.Fomin's studies, “...for great cities, a concentric development in lo-cal set of inhabited localities is typical. How-ever, in case of their excessive growth, a need arises in dispersal of planning structure ...up-to-date phase of development of the greatest cities required to return to group forms, but already on the larger scales not only on a lo-cal, but on the regional level as well" [6, p. 51-53].

«There are two typical varieties of the process of agglomeration for inhabited localities: concentration - growth in the central direction that leads to combining settlements; dispersal - growth in the direction from the center that is completed in the group form of settlements.

These two forms of development are inherent in the same city's agglomerations. Under certain conditions, arises a group form in the arrangement of cities, then due to intensifying functional links and development of general infrastructure, preliminary conditions are created for their planned unifying. With time, again preliminary conditions may be created for the new phase of dispersal" (Fig.1) $[6$, p.49, 50].

\section{ARAREAS OF INFLUEENCE}

In this plane, «...development of cities should be considered taking into account a

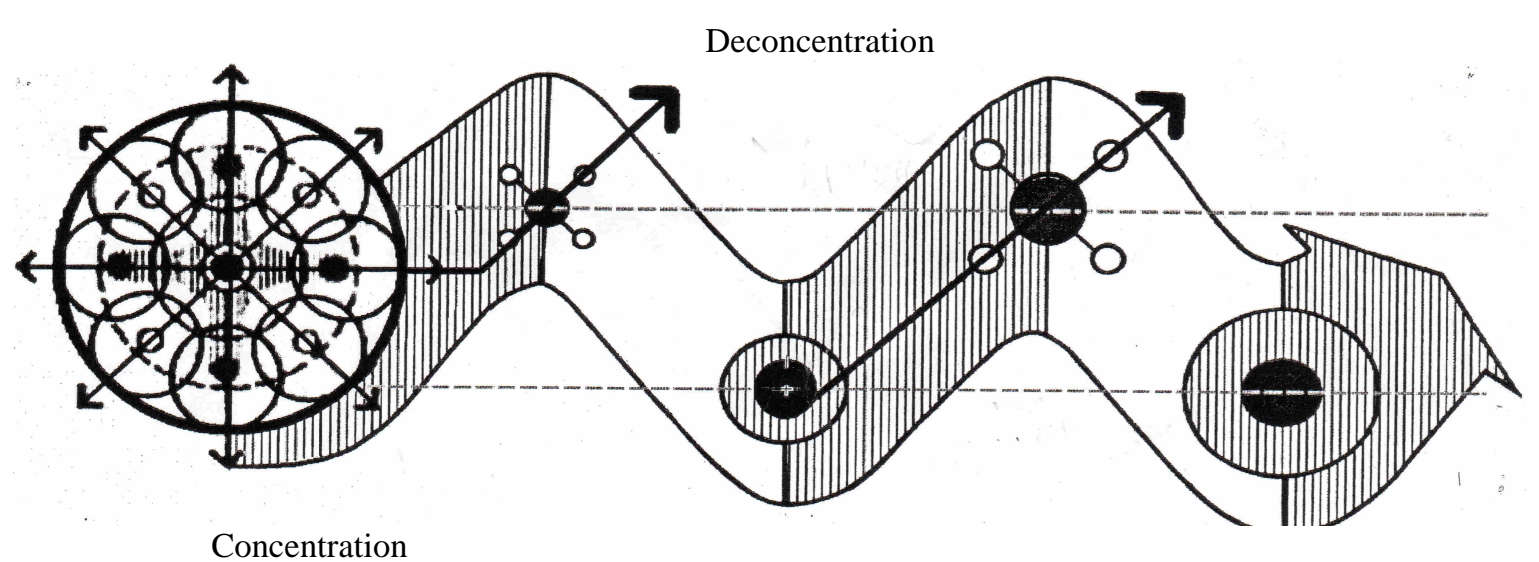

Fig.1. Cyclicity of forms of development of inhabited localities according to I.Fomin 
possible alternate transition from one structural form to the other. Development of planned structure in its certain form as if it comes to a certain critical point - boundary when its advantages become minimal and drawbacks hypertrophied. In this period, new radical measures must be undertaken for its implementation on the greater scale and at the higher level of structural complexity» (see Fig.1) [6, p.54-55].

As the criterion of estimation of spatial interaction level in the group systems of settlement of different level of their spatial integrity, M. Dyomin considers mobility of population. In this sense, he proposes to adopt "relation of population movability" to the institutions of everyday and periodic usage as the index that characterizes "power of influence" of the citycenter [7, p.71]. Probably, it is this difference of powers of influence of city-centers of local, regional and world levels causes the origin of the set of concentric zones in the cities' accessibility (Fig.2).

\section{FRACTALITY OF SPATIAL STRUCTURES}

Fractality of concentric structures in the multi-level developing of ecologic space, we have considered on the example of formation and development of areas of influence in Kiev according to the data of studies conducted by M.Dyomin and Yu.Bilokon' [7, 8]. As M.Dyomin notes, «in structural relation on the territory of areas of influence of the largest cities, we can with sufficient certainty to single out a number of belts qualitatively notable for the nature and intensity of socio-economic links" [7, p.71]. As for the areas of Kiev influence, its «first belt that directly adjacent to the city is created, for the most part by agricultural and working townships", that «...are located at the distance of $10 \ldots 12 \mathrm{~km}$ from the city. The second belt covers the territory with settlements the inhabitants of which regularly make use of services of city's institutions of periodical and episodic service" [7, p.72].
Intensity of trips to the city-center is determined by «the outer boundary of the second belt of great cities" that allows consider it as "the boundary of labor attraction" - $45 \mathrm{~km}$ ". The third - outer belt of the area of recreational and everyday influence depends on the size of the city-center, its administrative functions, character of national-economic and town planning development of district territory, nature of external transport communications" - 70 km (Fig. 2, a) [8, p.73].

Metropolitan status of Kiev determined the appearance of the fourth - interregional belt that covers the territory of Kievs'ka, Zhitomirs'ka, Chernigivs'ka and Cherkas'ka regions (see, Fig.2, b) [8, p.98-99]. Parameters of belts indices of areas of Kiev influence are shown in Table 1.

The fifth belt of area of Kiev influence (transnational) is being formed nowadays. As Yu.Bilokon' notes, a new significance of Ukraine in European space and multi-sectoral ties with countries of Western Europe urge "...the need of not only political and economic integration of all countries of European continent, but in spatial-planning aspect as well" [9, p.107].

Taking into consideration a geographic location of Ukraine and a zone of three-hour accessibility of Kiev airports that practically covers the whole Europe and the north of Africa, Yu. Bilokon' puts forward a conception of “... planned integration of countries of Eastern Europe into a general European territorial structure...it is a question of the urbanistic conception of organization of "expanded" European space for a faraway perspective taking into account general trends of integrational political and economic processes" (Fig.2,c) [9, p.107].

In the context of our studies, the area of influence of city-center has been considered as a multi-level space of support of life activities of the ecologic-urban planning system -"population $\leftrightarrow$ environment" $[9-11]$. Data shown in Table 1 allowed obtain additional indices of degree of development and perspectives of continuous development of this system (Table 2). 

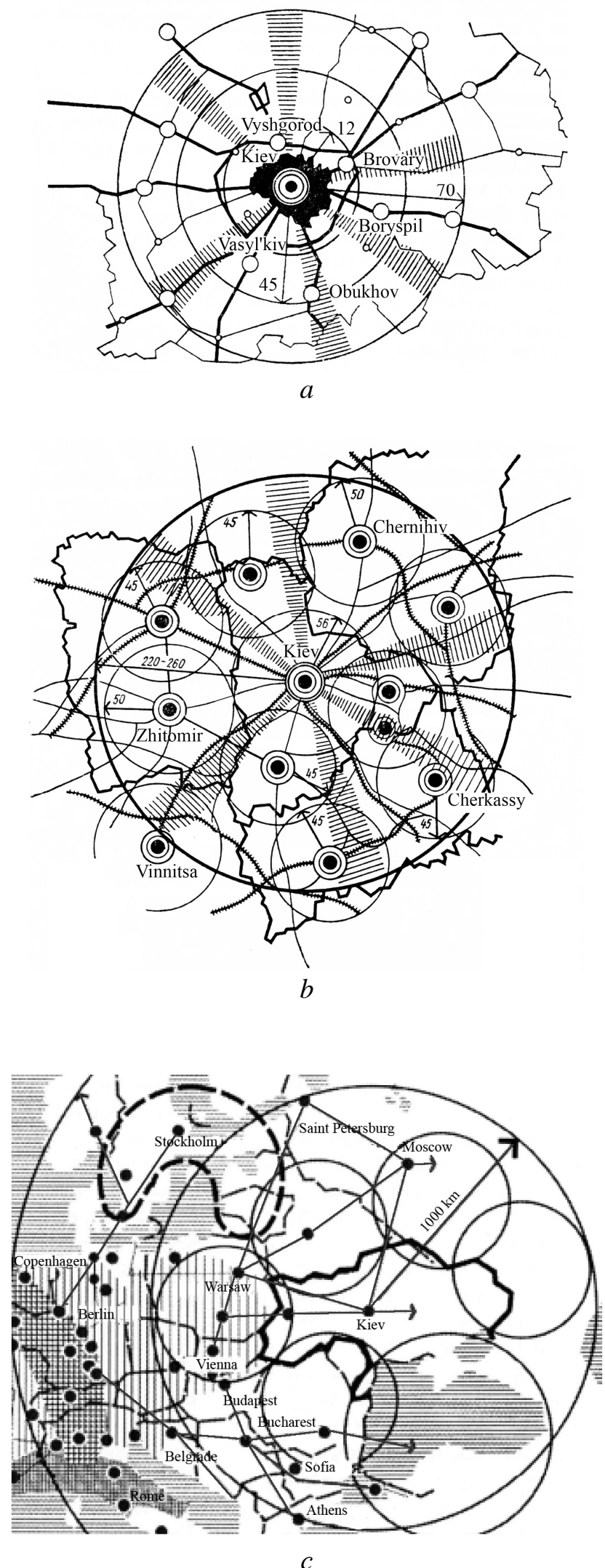

Fig.2. Space-donut development of Kyiv city agglomeration $(a)$ and Kyiv capital region $(b)$ by M.Dyomin. Ukraine in structure of European space by Y.Bilokon $(c)$ 
Table 1. Parameters of indices by the levels of spatial integrity of urban planning system according to M.Dyomin [7, p.89].

\begin{tabular}{|l|c|c|c|c|}
\hline \multirow{2}{*}{ Indices and their measurements } & \multicolumn{4}{|c|}{ Level of integrity } \\
\cline { 2 - 5 } & primary & topical & local & regional \\
\hline $\begin{array}{l}\text { Number of population of city-center, } \\
\left(\mathrm{P}_{\mathrm{c}}, \text { ths. persons) }\right.\end{array}$ & $1-2$ & $5-7$ & $50-150$ & $1000-2000$ \\
\hline $\begin{array}{l}\text { Number of population in the area of in- } \\
\text { fluence, }\left(\mathrm{P}_{\mathrm{ai}}, \text { ths. persons) }\right.\end{array}$ & $0,3-1$ & $8-20$ & $50-90$ & $2000-5000$ \\
\hline Area of territory, $\left(\mathrm{S}\right.$, ths.km $\left.{ }^{2}\right)$ & $0,08 \ldots 0,12$ & $0,3 \ldots 0,7$ & $3 \ldots .5$ & $70 \ldots 120$ \\
\hline $\begin{array}{l}\text { Radius of area of influence in space, } \\
(\mathrm{L}, \mathrm{km})\end{array}$ & $5 \ldots 7$ & $10 \ldots 15$ & $30 \ldots 40$ & $150 \ldots 200$ \\
\hline $\begin{array}{l}\text { Radius of area of influence with time, } \\
(\mathrm{T}, \mathrm{min})\end{array}$ & $15 \ldots 20$ & $30 \ldots 40$ & $60 \ldots 90$ & $120 \ldots 150$ \\
\hline
\end{tabular}

Table 2. Averaged parameters of indices according to the levels of integrity of ecologic-urban planning system "population environment"

\begin{tabular}{|l|c|c|c|c|}
\hline \multirow{2}{*}{\multicolumn{1}{|c|}{ Indices and their measurements }} & \multicolumn{4}{|c|}{ Level of integrity } \\
\cline { 2 - 5 } & primary & topical & local & regional \\
\hline $\begin{array}{l}\text { Number of population EUPS: city-center }- \\
\text { area of influence, }\left(\mathrm{P}_{\Sigma}, \text { ths. persons) }\right.\end{array}$ & 2,2 & 20 & 170 & 5000 \\
\hline Population density, $(\rho$, persons/km²) & 21,5 & 40,0 & 42,5 & 52,6 \\
\hline $\begin{array}{l}\text { Module of space of human life activities, } \\
\text { (M, ha/person) }\end{array}$ & 0,5 & 0,3 & 0,2 & 0,2 \\
\hline $\begin{array}{l}\text { Average speed of movement, } \\
(\mathrm{V}, \mathrm{km} / \mathrm{hour})\end{array}$ & 20,6 & 21,4 & 27,9 & 77,8 \\
\hline
\end{tabular}

However, for the analysis of constancy of developmental processes not as much "the external" characteristics of dynamics of EUPS components that are caused by a change of indices taking into account the levels of its integrity as "the internal" characteristics that are caused by the change of their speed and accelerations $[10,11]$.

\section{MULTI-LEVEL ACCELERATION OF PROCESSES OF DEVELOPMENT}

Having based on the data of Tables 1 and 2, "triangles of spatial changes" of rates and accelerations of indicated indices are constructed in Fig. 3 in consecutive "transition" of process- es of EUPS development to the higher territorial level of integrity of ecologic space $[2,9-11]$.

In Fig.3 all vertical triangles (solid line) have scales of relative accelerations of the rate of changes (") considered indices. Here, the internal vertical triangles (more saturated shade) characterize the rate of relative accelerations in changes of indicated indices in the transition of developmental processes from topical to local level, in relation to those that have occurred in the transition from primary to topical level. The external vertical triangles characterize the rate of relative accelerations of changes of the same indices in the transition of developmental processes from a local to regional 

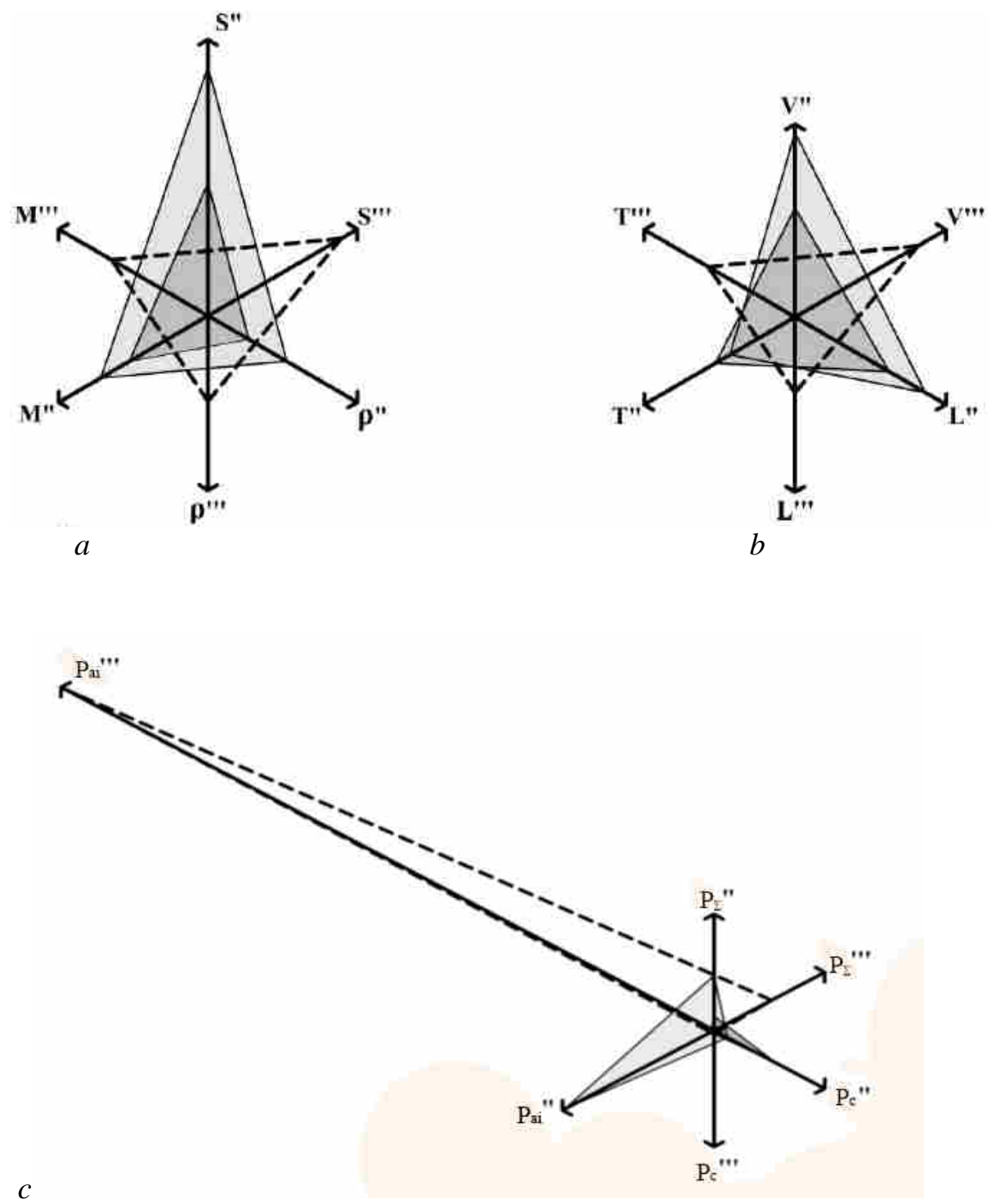

Fig.3. Changes of rates and accelerations of developmental processes of ecologic-urban planning systems in "the transition" of spatial levels

level in relation to those that have occurred in the transition from topical to local level. In its turn, horizontal triangles (dotted line) have scales of changes of relative accelerations of considered characteristics ("') that characterize angular acceleration of relative changes of wave process (see Table 1, 2; Fig.3).

In the group of indices of the territorial area increase acceleration ( $\mathrm{S}$ ), population density ( $\rho)$ and spatial module of human life-support the inverse value to the population density (M), in the transition of levels most likely the rate of EUPS area increase ( $S^{\prime \prime}$, index) and its acceleration (S"', index) (Fig.3,a) are changed.
In the group of acceleration indices of the area of influence radius increase of the citycenter in the space (L) and time (T) as well as the rate of movement $(\mathrm{V})$ in the transition of developmental processes for the levels of EUPS, spatial integrity, the rate ( $\mathrm{V}^{\prime \prime}$, index) and the acceleration of the rate of movement (V"', index) increase most rapidly (Fig.3,b).

In Fig.3,b, a certain inversibility in the directions of acceleration of changes in the radius of area influence of the city-center in space and time is traced. Thus, in the process of increase, in the consecutive spatial expansion of the radius of area of influence of the citycenter in kilometers, occurs a reduction of ra- 
dius of the area of its influence in hours. «Time compression» is shown by the fact that in Fig. $3, b$ the external triangle by the scale «T"» «enters» into the middle of the internal one. Noted above may be a peculiar manifestation of toral structures dynamics of the spacetime continuum when "the exterior shows itself inside of the interior" [11 - 13].

In the group of indices of acceleration of the increase in the total number of population $\left(\mathrm{P}_{\Sigma}\right)$, the number of population in the citycenter $\left(\mathrm{P}_{\mathrm{c}}\right)$ and the number of population in the area of its influence $\left(\mathrm{P}_{\mathrm{ai}}\right)$ in the transition of developmental processes in accordance with the spatial levels of integrity, the rate $\left(\mathrm{P}_{\mathrm{a}}{ }^{\prime}\right.$, index) and acceleration of relative increase in the number of population in the area of influence $\left(\mathrm{P}_{\mathrm{a}}{ }^{\prime \prime}\right.$, index $)$ are most likely changed (Fig. 3, c).

In Fig.3,c, a jump-like transition of significance of changes in the increase of the number of population is traced. So, in the internal vertical triangle that characterizes the rate of relative changes of the considered characteristics in the transition from topical to a local level, in relation to the transition from a primary to the topical level prevails the rate of increasing the number of population of the city-center (proportion between $\mathrm{P}_{\mathrm{c}}$ " and $\mathrm{P}_{\mathrm{ai}}$ " is equal to $18: 1)$.

In the external vertical triangle that characterizes the rate of relative changes in the same characteristics, in the transition of processes of development according to spatial levels from the local to regional in relation to the transition from topical to local level, the inversed change in the direction and location of action of the urbanization process is observed, in which the rate of increase in the number of population of the area of influence in considerably less significance of dynamics in the number of population in the city-center (proportion between $\mathrm{P}_{\mathrm{ai}}{ }^{\prime \prime}$ та $\mathrm{P}_{\mathrm{c}}$ " is equal to $\left.11: 1\right)$ becomes dominating.

Space-time transitions of urbanization processes of development can be considered at various points of view: in the aspect of elaboration of principles of the underwater urban planning [14], reconstruction of centers of historical places [15] or social history [16].

\section{RESULTS AND EXPLANATIONS}

The result, that is obtained, coincides with the results of I. Fomin's studies and, to the certain extent, describes the above dynamics of toral structure that this time shows itself in the varieties of agglomeration process, where the forms of "to the center and from the center" development are inherent in one and the same city's agglomerations. Dynamics of this structure reflects a concentration of population and spatial development directed to the center at the primary-topical level of development of urbanization process; dispersal of population and such development directed from the center in the transitions of developmental processes from a local to a regional level (see Figs. 1 - 3; Tables 1, 2).

Process, directed from the center, yet more graphically reveals a horizontal triangle in Fig.3.c that characterizes the acceleration of relative changes in the number of population in the area of influence, in the transition of processes of development from local to regional level and in relation to the transition of processes of development from topical to local level (see, Table 1). This triangle reveals significant dominance (by two orders) of acceleration of increase in the number of population in the area of influence $\left(\mathrm{P}_{\mathrm{ai}}{ }^{\prime \prime}\right.$, index) over the acceleration of increase of population in the city-center $\left(\mathrm{P}_{\mathrm{c}}{ }^{\prime \prime}\right.$, index). Proportion between $\mathrm{P}_{\mathrm{ai}}{ }^{\prime \prime \prime}$ and $\mathrm{P}_{\mathrm{c}}{ }^{\prime \prime}$ is equal to 198:1 (see, Fig.3, c).

It should be noted that in the space-time [LT] system of measurement [3, 17] of parameters of development of ecologic-urban planning systems $\mathrm{P}^{\prime \prime}$ has the value $\left[\mathrm{L}^{3} \mathrm{~T}^{-4}\right]$, that according to our studies corresponds to the angular acceleration of mass [2, 12, 13]. Relatively angular acceleration. According to O. Kuznetsov, this acceleration is the cause of gravitation $[3,17]$. In this sense, cities can be considered as "gravitation" centers, "the power of influence" of which extends concentrically in the space of ecologic-urban planning systems (see Fig.2). In the process of urbanization, the author investigated and other physical parallels $[2,18-20]$.

From the mentioned above, it follows that cyclically wave character of development of 
cities and city's agglomerations (see Fig.1) is caused by the change in the rates and accelerations of changes in the EUPS basic parameters: number of population of the city-center $\left(\mathrm{P}_{c}\right)$ and the area of influence $\left(\mathrm{P}_{\mathrm{ai}}\right)$, radii of the areas of influence of cities-centers in hours (T) and in kilometers (L) at the primary, sectional, local and regional levels (see Fig.3).

That is in the multi-level transitions of developmental processes, agglomeration form of group settlement gains the signs of the system that reduces the time interval $(1,1 \rightarrow 0,9)$ and significantly expands it in space $(1,3 \rightarrow 1,8)$ (see Fig.3, $b$ ). Indicated changes in the multilevel dynamics of space-time boundaries of ecologic-urban planning systems and modern world of Internet communications that synchronizes processes in time and overcome bounds in space, can lead to the structural reconstruction of settlement.

\section{CONCLUSIONS}

1. Non-uniformity in developing of space and formation of group systems of settlement are associated with economic progress and development of engineering and transport, information and communication networks.

2. Index that characterizes "the power of influence" of the city-center of group system of settlement is "the relation of mobility" of population to the establishments of everyday and periodic usage.

3. In consecutive transition of processes of development from local to regional and interregional levels of integrity of the ecologic space, some inverse changes of space-time boundaries of ecologic-urban planning system occur.

4. For the analysis of processes of multilevel development of ecologic-urban planning systems are important not only measurements of dynamics of their indices, but characteristics of changes of this dynamics and their acceleration.

\section{REFERENCES}

1. Gutnov A.E, 1984. Evolution of town planning. Moscow, Stroyizdat, 296 (in Russian).
2. Ustinova I.I., 2016. The Methodological Foundations of Sustainable Development of Ecological and City-Planning Systems. Abstract of a Thesis on Achieving of Degree of Doctor in Architectural Sciences, Spec. 18.00.01 Theory of Architecture, Restoration of Architectural Monuments. Kyiv, 46 (in Ukrainian).

3. Kuznetsov O.L., Bolshakov B.E., 2002. Sustainable development: Scientific Fundamentals of Designing a System Nature-Society-Man: Training. [For the students of Higher Educational Establishments]. St.-Petersburg-Moscow-Dubna, Humanystyka, 616 (in Russian).

4. Melnyk L.G., 2005. Secrets of development. Sumy, University book, 378 (in Russian).

5. Zhurovskyy M.Z., Hvyshyany A.D., 2008. Global modeling of processes in the context of sustainable development in the context of quality and safety of life of people (2005-2007/2008). Kyiv, NTU KPI Polytehnyka, 331 (in Russian).

6. Fomin I.A., 1986. City in the system of inhabited localities. Kyiv, Budivelnik, 112 (in Russian).

7. Dyomin N.M., 1991. Management by development of town-planning systems. Kyiv, Budivelnik, 185 (in Russian).

8. Bilokon Y.M., 2003. Regional planning (theory and practice). Kyiv, Logos, 246 (in Ukraine).

9. Ustinova I.I., 2014. Urban processes in ecological space. Town-planning and territorial planning, Kyiv, KNUCA, Vol.53, 549-554 (in Ukrainian).

10. Ustinova I.I., 2007. Looping of oscillatory development of ecological and town-planning systems. Modern problems of architecture and urban planning, Kyiv, KNUCA, Vol.17, 182-190 (in Ukraine).

11. Iryna Ustinova, 2015. Theoretical principles of wave urbanistics. Underwater Technologies, Vol.01, 33-42.

12. Iryna Ustinova, Anastasiia Chubarova, 2016. Spatial-Temporal Dimensions and Principles of Sustainable Development of Ecological and CityPlanning Systems. Motrol, Vol.18, Nr 10, 25-32.

13. Ustinova I.I., 2013. Universal spatiotemporal definitions of urbanization in the context of sustainable development. Euro-eco Internationaler Kongress. Hannover Europäische Akademie für Naturwissenschaften, 139-140.

14. Ludmila Ruban, 2016. Underwater urban studies: modern issues and trends. Underwater Technologies, Vol.03, 54-65 (in Ukrainian).

15.Eugenia Kazakova, 2017. Problems and directions of reconstruction of historical centers of small settlements of the Volyn region (on the ex- 
ample of Klevan, Rivne region). Underwater Technologies, Vol.05, 84-91 (in Ukrainian).

16.Ludmila Bachinska, 2017. The development of the archi-tectural object under the influence of social history. Underwater Technologies, Vol.06, 89-99.

17. Kuznetsov O.L., Bolshakov B.E., 2000. NatureSociety-Human system. sustainable development. http://www.situation.ru/app/rs/lib/pobisk/systema/ main.htm (in Russian).

18. Ustinova, I., 2007. The environmental paralels of the physical laws in the process of urban ecological systems. Modern problems of architecture and urban planning, Kyiv, KNUCA, Vol.18, 184-191 (in Ukrainian).

19. Ustinova, I., 2008. The physical parallels of environmentally sound development. Modern problems of architecture and urban planning, Kyiv, KNUCA, Vol.20, 229-233 (in Ukrainian).

20.Ustinova, I., 2009. The eco-physical similarity of urbanization. Modern problems of architecture and urban planning, Kyiv, KNUCA, Vol.22, 293298 (in Ukrainian).

\section{Фрактальность концентрических структур в пространстве эколого- градостроительных систем}

\section{Ирина Устинова}

Аннотация. Рассмотрены условия и этапы формирования фрактально вложенного множества концентрических зон доступности городов на примере Киева. Количество «уровней вложенности» такого множества зависит от привлекательности и статуса города.
Установлено, что неоднородность освоения пространства связана с экономическим развитием и развитостью инженерно-транспортных сетей. Быстрый рост этих сетей ведет к превращению традиционно центрального типа неравномерности освоения пространства в многоядерные групповые системы расселения.

В зоне влияния Киева выделяется пять качественно отличающихся по интенсивности социально-экономических связей и скорости передвижения поясов. На основе количественных характеристик этих поясов установлено, что при последовательном переходе процессов развития от локального к региональному и межрегиональному уровням целостности эколого-градостроительной системы «населениењсреда», происходит расширение ее пространственных границ и своеобразное «сжатие» временных, что проявляется скачкообразным увеличением радиуса зоны влияния города-центра системы расселения в километрах.

Для анализа процессов многоуровневого развития эколого-градостроительных систем важны не столько динамика показателей развитости, сколько характеристики их ускорений.

Ключевые слова: устойчивое развитие, фрактальность, пространственные структуры, эколого-градостроительные системы, зоны влияния городов. 